\title{
BUSINESS, HUMAN RIGHTS AND CHILDREN: THE DEVELOPING INTERNATIONAL AGENDA
}

\author{
Olga Martin-Ortega and Rebecca Wallace*
}

\section{INTRODUCTION}

Business activities may have a significant impact on human rights including those of children who are no less susceptible to the potential effects than adults. That impact may not be adverse and can be positive. It may be indirect, for example via children's parents' and carers' access to resources and enjoyment of their own rights, or from affecting children's communities and environments in which they live. The impact may also be direct, through children's inclusion among the work force. Moreover business activities have effects on their health and wellbeing, for example when children are the consumers of products and services provided by businesses.

Consideration of the role of the private business sector with regards to the fulfilment of children's rights is relatively recent. International attention on the effects business activities have on children has been fragmented until now, focussing on specific sectors, mainly child labour and economic exploitation. Recent international developments, addressed to states and business enterprises, propose a more comprehensive approach. This article focuses on two: the UNICEF-Global Compact and Save the Children Children's Rights and Business Principles (CRB Principles), launched in May 2012, ${ }^{1}$ and the Committee on the Rights of the Child's General Comment No. 16 on state obligations regarding the impact of the business sector on children's rights, published in April 2013. ${ }^{2}$ Both documents represent an important step in the consolidation of an international agenda for the protection of the rights of the child that takes into account the different challenges faced by children in the current economic system. These documents are a further step in the

\footnotetext{
* Dr Olga Martin-Ortega is Reader in Public International Law, University of Greenwich and Professor Rebecca Wallace is Professor in International Human Rights and Justice, Robert Gordon University. The authors would like to acknowledge the research assistance of Karen Wylie, Robert Gordon University.

${ }^{1}$ UNICEF, Global Compact and Save the Children Children's Rights and Business Principles, 2012:

http://www.unglobalcompact.org/docs/issues_doc/human_rights/CRBP/Childrens_Ri ghts_and_Business_Principles.pdf

${ }_{2} \mathrm{CR} / \overline{\mathrm{C}} / \mathrm{GC} / 16, \overline{15}$ March 2013. The General Comment was adopted on the Committee's sixty-second session (14 January - 1 February 2013).
} 


\section{BUSINESS, HUMAN RIGHTS AND CHILDREN: THE DEVELOPING INTERNATIONAL AGENDA}

development of a comprehensive approach which takes into consideration all the actors involved in the protection and promotion of children's rights, and moves away from a solely state-centric conception of international human rights obligations and responsibilities.

The specific focus on how business activities impact children's rights is a recognition that not only the actions (or inaction) of the state affects their rights but it follows a general demand for businesses, as organs of society, to undertake responsibility in the fulfilment of human rights. In particular with regards to children's rights, it follows the increased recognition of children as socio-economic rights bearers, independently of the society or family unit of which they form part. $^{3}$ This article analyses the two recent instruments mentioned as well as providing insight on their potential impact in the developing agenda for business and children's rights. Initially, it is important to contextualise these documents' adoption within wider business and human rights policy and other normative developments.

\section{THE BUSINESS AND HUMAN RIGHTS FRAMEWORK}

Advances in technology have hastened the sharing of information and it is harder for businesses to hide behind closed doors. Business enterprises face greater scrutiny and their decisions are publicised around the world. As a consequence of the globalisation of goods and services and increasing consumer awareness, it is no longer feasible to hold that the only responsibility of business is to accrue profit. Financial gain may still remain the primary objective of business enterprises, but arguably this cannot now be pursued at any cost.

\section{The Global Compact and UN Norms}

The role of business vis-à-vis human rights has come in for greater international consideration since the mid 1990s, when the UN human rights bodies started to pay attention to the negative impact of globalisation on human rights. ${ }^{4}$ More specifically, in 1999, the UN Secretary General presented the Global Compact to the business community. The Global Compact comprises ten principles addressing human rights, labour standards,

\footnotetext{
${ }^{3}$ A Nolan, Children's Socio-Economic Rights, Democracy and the Courts (Oxford, Hart Publishing 2011) 7.

${ }^{4}$ The extinct UN Commission on Human Rights appointed two Special Rapporteurs on the issue of globalization and its impact on the full enjoyment of human rights. See, UN Commission on Human Rights Resolution 1999/59, Globalization and its impact on the full enjoyment of all human rights, E/CN.4/RES/1999/59, 28 April 1999.
} 
the environment and corruption. ${ }^{5}$ It is non-legally binding and not intended as a normative instrument. All that is required of businesses is to publicly sign up to the Global Compact's principles voluntarily and integrate them into commercial practices, including the relations with business partners. The Global Compact is an important tool for dialogue and awareness raising regarding the role of business in society and its capacity to respect, protect and promote human rights. However, its voluntary nature, along with the lack of a robust monitoring mechanism, denies its capacity to be more than that.

In parallel to the process of launching and promoting the Global Compact the UN Sub-Commission on the Promotion and Protection of Human Rights undertook the task of drafting a human rights instrument for business. In 2006 it proposed Norms on the Responsibilities of Transnational Corporations and Other Business Enterprises with Regard to Human Rights. The Norms adopted a bolder stance relating to the weight placed upon business enterprises claiming that:

"Within their respective spheres of activity and influence, transnational corporations and other business enterprises have the obligation to promote, secure the fulfilment of, respect, ensure respect of and protect human rights recognized in international as well as national law, including the rights and interests of indigenous peoples and other vulnerable groups."

The Norms proved to be highly divisive. Although eagerly welcomed by some human rights groups and academics, states and the business sector were decisive in their rejection of the Norms. ${ }^{7}$ The main point of contention lay in the Norms' attempt to attribute human rights duties to business, which envisaged legally binding obligations.

\section{The UN Guiding Principles}

The current framework was put forward by John Ruggie who was appointed as Special Representative to the Secretary-General on the issue of human rights and transnational corporations and other business enterprises in

\footnotetext{
${ }^{5}$ UN Global Compact, The Ten Principles; http://www.unglobalcompact.org/AboutTheGC/TheTenPrinciples/index.html.

6 UN Sub-Commission for the Protection and Promotion of Human Rights, E/CN.4/Sub.2/2003/12/Rev.2 (2003), at Section A.1, 4, (emphasis added).

7 See R M M Wallace and O Martin-Ortega, 'The UN Norms: A First Step to Universal Regulation of Transnational Corporations' Responsibilities for Human Rights?' (2004) 26 Dublin University Law Journal 304-319.
} 


\section{BUSINESS, HUMAN RIGHTS AND CHILDREN: THE DEVELOPING INTERNATIONAL AGENDA}

$2005 .{ }^{8}$ Over the following six years Ruggie developed the UN framework, the 'Protect, Respect and Remedy' Framework' ${ }^{9}$ and guidance for its implementation: the UN Guiding Principles on Business and Human Rights (hereinafter the Guiding Principles). ${ }^{10}$ These were presented to and endorsed by the Human Rights Council on June 16, 2011. ${ }^{11}$ The Guiding Principles are grounded in recognition of:

“(a) States' existing obligations to respect, protect and fulfil human rights and fundamental freedoms;

(b) The role of business enterprises as specialized organs of society performing specialized functions, required to comply with all applicable laws and to respect human rights;

(c) The need for rights and obligations to be matched to appropriate and effective remedies when breached." 12

As can be seen from this the Guiding Principles avoid the controversy created by the Norms in that Ruggie clearly differentiates the roles for states and businesses, namely that the former has the obligation to respect, protect and fulfil human rights whereas businesses are expected to respect human rights. This was obviously a politically expedient move on Ruggie's part and he succeeded in gaining consensus with his criticism of " 'the Norms' exaggerated legal claims' that human rights law directly imposes a wide spectrum of duties on corporations." ${ }^{, 13}$ Furthermore Ruggie insisted on behalf

${ }^{8}$ Ruggie was appointed by then UN Secretary-General Kofi Annan under, UN Commission on Human Rights, Resolution 2005/69, Human Rights and Transnational Corporations and Other Business Enterprises, E/CN.4/RES/2005/69, 20 April 2005. Ruggie is Berthold Beitz Professor of International Affairs, Harvard's Kennedy School of Government, and Affiliated Professor in International Legal Studies at Harvard Law School.

${ }^{9}$ Report of the Special Representative of the Secretary-General on the issue of human rights and transnational corporations and other business enterprises, John Ruggie, Protect, Respect and Remedy: a Framework for Business and Human Rights, A/HRC/8/5, 7 April 2008.

${ }^{10}$ Report of the Special Representative of the Secretary-General on the issue of human rights and transnational corporations and other business enterprises, John Ruggie, Guiding Principles on Business and Human Rights: Implementing the United Nations 'Protect, Respect and Remedy' Framework, A/HRC/17/31, March 21, 2011.

11 Human Rights Council, Resolution 17/4, Human rights and transnational corporations and other business enterprises, A/HRC/RES/17/4, 6 July 2011.

${ }^{12}$ Guiding Principles, (n. 10) at 6.

13 JH Knox, The Human Rights Council Endorses 'Guiding Principles' for Corporations, ASIL Insight, August 1, 2011, Volume 15, Issue 21, 2.

http://www.asil.org/pdfs/insights/insight110801.pdf. 
of business enterprises "the responsibility [to respect human rights] stems from societal expectations rather than human rights law." 14

The Guiding Principles are aimed primarily at states and are divided into three sections. Section I relates to the state duty to protect human rights (Principles $1-10$ ). The founding principle is that states must "protect against human rights abuses within their territory and/or jurisdiction by third parties, including business enterprises." 15 The onus lies with states to "set out clearly the expectation that all business enterprises domiciled in their territory and/or jurisdiction respect human rights throughout their operations." $" 16$

However the Guiding Principles, in Section II (Principles $11-24$ ), also address the responsibilities of business enterprises and what is expected of them in relation to human rights, namely that they should "avoid infringing on the human rights of others and should address the adverse human rights impacts with which they are involved." $"$ The means by which this end should be sought is prescribed in Guiding Principle 15 which provides businesses must have:

"(a) a policy commitment to meet their responsibility to respect human rights; (b) a human rights due diligence process to identify, prevent, mitigate and account for how they address their impact on human rights; (c) processes to enable the remediation of any adverse human rights impacts they cause or to which they contribute."

As this demonstrates the responsibility for businesses to respect human rights is not a passive one but requires businesses to actively put in place the means to execute this responsibility. Businesses are expected to base their activities on the exercise of due diligence and have in place the processes and mechanisms to track, monitor and respond to any negative human rights impact their activities create. They are also required to implement systems to communicate widely any responses. Human rights due diligence can be included within broader enterprise risk-management systems or be a separate, specific process. Either way it should go beyond identifying risks for the company to include risks to rights-holders. This involves assessing the human rights context prior to commencing a business activity, where possible; identifying who may be affected; cataloguing the relevant human rights

\footnotetext{
${ }^{14}$ Ibid (emphasis in original).

${ }^{15}$ Guiding Principle 1. The full text of the Guiding Principles and accompanying commentary can be accessed at:

http://www.businesshumanrights.org/media/documents/ruggie/ruggie-guidingprinciples-21-mar-2011.pdf.

${ }^{16}$ Guiding Principle 2.

${ }^{17}$ Guiding Principle 11.
} 


\section{BUSINESS, HUMAN RIGHTS AND CHILDREN: THE DEVELOPING INTERNATIONAL AGENDA}

standards and issues; and projecting how the proposed activity and associated business relationships could have adverse human rights impacts. These risks should be periodically reassessed throughout the lifespan of an activity or business relationship. ${ }^{18}$

Section III of the Guiding Principles (Principles 25 - 31) is concerned with access to remedy for those whose rights have been violated by business activity. States "should provide effective and appropriate non-judicial grievance mechanisms alongside judicial mechanisms." to the Guiding Principles recognises "[u]nless States take appropriate steps to investigate, punish and redress business related human rights abuses when they do occur, the State duty to protect can be rendered weak or even meaningless. $" 20$ Equally, the Guiding Principles require businesses to establish or participate in operational-level grievance mechanisms in order to provide effective means of redress for individuals and communities who may be adversely impacted (Principle 29).

It remains the case though that the Guiding Principles are non-legally binding and are of a voluntary nature. Also the tools suggested by the Guiding Principles such as human rights impact assessments will often be developed, conducted and evaluated by the business enterprises themselves. This constructs an environment of self-regulation that could be open to abuse or apathetic monitoring. Also, although the Guiding Principles address the need for states to ensure those whose human rights have been violated by the activities of businesses have access to effective remedies, they have been criticised for giving little attention to judicial remedy and for a lack of clarity regarding corporate liability for gross human rights abuses. ${ }^{21}$

However despite these criticisms there has emerged a set of standards to which business is expected to comply in relation to human rights. The Guiding Principles have thus far been well received and have precipitated discussion at national and regional levels for developing national action plans to implement the framework. ${ }^{22}$

\footnotetext{
${ }^{18}$ Commentary to Guiding Principle 18.

${ }^{19}$ Guiding Principle 27.

${ }^{20}$ Commentary to Guiding Principle 25.
}

21 See, for example, the summary of discussions of the Forum on Business and Human Rights, prepared by the Chairperson, John Ruggie, A/HRC/FBHR/2012/4, 23 January 2013,

http://www.ohchr.org/Documents/Issues/Business/ForumSession1/A_HRC_FBHR_2 012 4_en.pdf.

${ }^{22}$ Several EU countries are embarked in the drafting of National Action Plans after the European Commission invited all member states to implement the UN Guiding Principles at national level in 2011, Communication from the Commission to the European Parliament, the Council, the European Economic and Social Committee and 


\section{BUSINESSES' FRAGMENTED APPROACH TOWARDS CHILDREN'S RIGHTS}

To date attention on the impact private sector activities has on children's rights has been fragmented and focussed on specific sectors, mainly child labour and the privatisation of public services. This section briefly explores the current legal framework with regards to the economic dimension of children's rights whilst the following analyses the recent developments towards a more comprehensive approach.

\section{Child Labour}

Most of the advances made in international law in relation to children's rights and business have focussed on child labour and child economic exploitation. The legal framework to combat child labour has evolved since the adoption of the 1989 Convention on the Rights of the Child (CRC), even if child labour and child exploitation remains a present and sad reality. Article $32 \mathrm{CRC}$ explicitly establishes that the child has the right to be protected from economic exploitation and from performing any work that is likely to be hazardous or to interfere with the child's education, or to be harmful to the child's health or physical, mental, spiritual, moral or social development. Equally, the Supplementary Convention on the Abolition of Slavery, the Slave Trade and Institutions and Practices Similar to Slavery, the Universal Declaration of Human Rights (art. 4), the International Conventions on Civil and Political Rights and Economic, Social and Cultural Rights (arts 8.2 and 10.3 respectively), all prohibit the economic exploitation of children. Specifically in the framework of the International Labour Organisation (ILO), child labour comes within the meaning of forced labour as regulated in the Convention concerning Forced or Compulsory Labour No. 29 and Convention concerning the Abolition of Forced Labor No. 105. Children's work is also regulated in the Minimum Age Convention No. 138 and Recommendation No. 146 and more specifically on the Convention on the Worst Forms of Child Labour No. 182. The recent ILO Convention on Domestic Workers No. 189 also contains references to a minimum age for children in domestic labour. The ILO Declaration on Fundamental Principles and Rights at Work, adopted in 1998, declared that the effective abolition of child labour is a principle to which all members of the ILO, even if they have not ratified the Conventions in question, have the obligation to respect, promote and realise. In all these international legal instruments establish a regime that

the Committee of Regions, A Renewed EU Strategy 2011-14 for Corporate Social Responsibility, COM(2011) 681 final, 25 November 2011. 


\section{BUSINESS, HUMAN RIGHTS AND CHILDREN: THE DEVELOPING INTERNATIONAL AGENDA}

distinguishes tolerable child labour from exploitative child labour, namely: labour performed under the minimum age established for specific types of work, which is likely to impede a child's education and full development, hazardous work and the worst forms of labour. ${ }^{23}$ Whilst the prohibition of child labour in international law does not form part of customary law yet, it can be argued that is a norm of ius cogens. ${ }^{24}$

The aforementioned instruments establish a clear framework of state obligations. They encompass the adoption of the necessary measures legislative, administrative, social and educational. Among the legal norms are included: minimum age legislation establishing criminal sanctions for noncompliance, preventative measures, labour inspections of private parties, removal of children from the worst forms of child labour, adequate educational measures and recovery, rehabilitation and integration of exploited children, as well as cooperation at the international level to further attain the eradication of child labour. ${ }^{25}$ States not only have a negative obligation to refrain from exploiting children but also a positive one to protect them from violations committed by third parties and to fulfil related obligations such as to provide free basic education, recovery, rehabilitation and social integration measures. The use of child labour is also the area on which businesses themselves have focused more prominently in their self-regulation attempts. The undertaking not to use child labour is one of the central, and nearly exclusive, corporate social responsibility commitments of business with regards to children. ${ }^{26}$

\section{Privatisation of Public Services}

Another aspect of business and human rights with regards to children which has received specific attention has been the impact of privatisation of public services. The consideration of the best interests of the child by private welfare institutions is already foreseen in the CRC (art. 3), but the increased privatisation of public services since the 1990s posed specific risks to which the Committee on the Rights of the Child (hereafter the Committee) has devoted particular attention since 2002. On 20 September 2002 the

\footnotetext{
${ }^{23}$ F Humbert, The Challenge of Child Labour in International Law (Cambridge, University Press 2009) 120.

24 Ibid.

25 Ibid.

${ }^{26} \mathrm{O}$ Martin-Ortega and R M M Wallace, 'The Interactions between International Law and Corporate Codes of Conduct: a Study of Women and Children in the Textile Industry' in S Tully (ed) The Research Handbook on Corporate Legal Responsibility (Cheltenham, Edward Edgar 2005) 302-315.
} 
Committee held a Day of General Discussion ${ }^{27}$ on the theme of "the private sector as service provider and its role in implementing child rights." 28 Among the main conclusions of the Committee are that states parties to the CRC have the primary responsibility for compliance with its provisions with regards to all persons within its jurisdiction. The legal obligation to respect and ensure the rights of children as stipulated in the Convention includes their obligation to ensure that non-state service providers operate in accordance with the provisions of the Convention, and the state continues to be bound by its obligations under the treaty, even when the provision of services is delegated to non-state actors. ${ }^{29}$ The Committee unequivocally states that the CRC creates indirect obligations on private service providers. ${ }^{30}$ The Committee specifically calls on them to respect the principles and provisions of the CRC, taking into account the four general principles set out in the provisions concerning non-discrimination (art. 2), the best interest of the child (art. 3), the right to life, survival and development (art. 6), and the right of the child to express his or her views freely (art. 12), when conceptualising, implementing and evaluating their programmes, including when subcontracting to other nonstate service providers. ${ }^{31}$ It further recommends developing self-regulation instruments and compliance mechanisms in accordance with the principles of

${ }^{27} \mathrm{UN}$ Committee on the Rights of the Child, Report on the Thirty-First Session, CRC/C/121, 11 December 2002, paras 629-659.The Committee has organised Days of General Discussion since 1992. Their purpose is to discuss a specialised topic of importance for the implementation of the CRC, as well as providing an opportunity for the Committee to engage in dialogue with representatives of state parties, NGOs and other UN agencies. As J Doek explains, in choosing the theme the Committee often follows the proposals made by NGOs. Recommendations are issued at the end of the discussion, which are approved by the Committee. They are meant to guide State Parties, NGOS, UN agencies and others with the implementation of the CRC, as well as serve as basis for the production of General Comments. They could have important consequences. For example, the appointment of the UN Special Representative of the Secretary General on Children in Armed Conflict followed a CRC Committee Day of General Discussion on the matter, which also contributed to the elaboration of the Optional Protocol to the CRC on Children in Armed Conflict. See, J E Doek, 'The CRC: Dynamics and Directions of Monitoring its Implementation' in A Invernizzi and J Williams, The Human Rights of Children. From Visions to Implementation (Farmham Ashgate, 2011) 104-105; see as well W Vandenhole, The Procedures Before the UN Human Rights Treaty Bodies. Divergence or Convergence? (Antwerp, Intersentia 2004) 189-190.

${ }^{28}$ UN Committee on the Rights of the Child, ibid: private sector encompasses business, non-governmental organisations and other profit-making and non-profit making private associations.

${ }^{29}$ Ibid, Recommendations, Legal Obligations, para 653.1.

${ }^{30}$ Ibid.

${ }^{31} \mathrm{Ibid}$, Recommendations to non-state service providers, para 653.16 . 


\section{BUSINESS, HUMAN RIGHTS AND CHILDREN: THE DEVELOPING INTERNATIONAL AGENDA}

the CRC. ${ }^{32}$ This approach was later reinforced in the Committee's General Comment 5 on General measures of implementation of the Convention on the Rights of the Child. ${ }^{33}$

\section{General Business and International Human Rights Instruments}

The initiatives specifically concerned with business and human rights have paid little particular attention to children's rights. Most of them include it in the general context of labour rights, as in the UN Norms ${ }^{34}$ and the UN Global Compact. The latter only mentions children with regards to the principle on the effective abolition of child labour (Global Compact, Principle 5). The UN Guiding Principles are silent on any references to children's rights in its main text and there are only two references in the commentary. These references include children in a wider category of vulnerable individuals, with women, national and ethnic minorities, religious and linguistic minorities, indigenous people, persons with disabilities and migrant workers and their families, when considering general state regulatory and policy functions (Commentary to Principle 3) and when listing the international legal instruments relevant to the responsibility of business (Commentary to Principle 12). This is certainly a limited range of references, and it is particularly unsatisfactory from a children's rights perspective that their needs are considered in the context of such a diverse group. The inclusion of children among other groups is problematic because children occupy a different position in society from that of other socially disadvantaged groups. ${ }^{35}$ Commentators have argued against considering children as members of a wider category of vulnerable people. In this regard, Nolan has highlighted that the inaccurate conceptualisation of children as vulnerable, dependent and passive results in the lack of recognition of, and therefore capacity to exercise, their agency. This gives rise to a vicious circle, in which "false perceptions of children are reinforced by, and give rise to, the limited opportunities available to children to demonstrate their competence and agency." 36 It must of course

${ }^{32}$ Ibid, para 653.17

${ }^{33}$ UN Committee on the Rights of the Child, General Comment 5 on General Measures of Implementation of the Convention on the Rights of the Child (arts 4, 42 and 44, para 6), CRC/GC/2003/5, 27 November 2003, paras 42-44.

${ }^{34}$ The UN Norms only had two mentions: an exception to the principle of nondiscrimination when the protection of children's rights required greater protection (art. 2) and, in the context of rights of workers, the prohibition of economic exploitation of children from transnational corporations and other business enterprises (art. 6), (n 6).

${ }^{35}$ Nolan, (n 3$) 10$.

${ }^{36}$ Ibid, p 11. As the author sustains, child dependency cannot be ended merely by social or political change: children are inevitably dependent, as they are always 
be noted that children are not a homogenous group. Given that childhood is accepted under international law to encompass individuals from birth to the age of 18 years old ${ }^{37}$ they obviously represent a large and diverse group. Equally, children in different socio-economic and political contexts face different challenges and needs, and accordingly the impact of business activities will differ.

As mentioned corporate self-regulatory regimes also refer to children, mostly with regards to child labour. Codes of conduct and corporate social responsibility schemes normally include provisions regarding the protection of children, concentrating on the commitment to fight child labour as part of their voluntary commitments and seldom refer to internationally recognised normative standards. ${ }^{38}$ Some of the most developed industry sector practices in this regard are found in the textile sector, sports merchandise and footwear. However it does not necessarily follow that the advances on paper have translated to great improvements in practice.

\section{TOWARDS COMPREHENSIVE APPROACHES FOR BUSINESS AND STATES}

Two important recent developments have heralded a more comprehensive approach in the efforts to tackle the negative impact of business activities on children's rights, pointing to joint responsibilities of states and business for the protection and promotion of children's rights. These instruments, analysed below, are addressed to business and to states respectively. They too highlight how new considerations towards the impact of business in children's lives are increasingly based on children as rights bearers, with agency and voice, rather than exclusively as objects of protection.

\section{UNICEF, GLOBAL COMPACT AND SAVE THE CHILDREN CHILDREN'S RIGHTS AND BUSINESS PRINCIPLES}

In 2012 UNICEF, the UN Global Compact and Save the Children called on businesses to step up their efforts to respect and support children's rights in the community, the marketplace and workplace. In furtherance of this, they published a set of ten principles designed to ensure that companies respect and support children's rights: the Children's Rights and Business Principles

members to a vulnerable group due to the fact that their vulnerability cannot be fully remedied by empowerment measures, 10-11.

${ }^{37}$ Article 1 of the United Nations Convention on the Rights of the Child 1 defines a child as meaning every human being below the age of eighteen years unless under the law applicable to the child, majority is attained earlier.

${ }^{38}$ For a thorough study see Martin-Ortega and Wallace, (n 26). 


\section{BUSINESS, HUMAN RIGHTS AND CHILDREN: THE DEVELOPING INTERNATIONAL AGENDA}

(hereinafter, CRB Principles). ${ }^{39}$ These Principles have been endorsed by the Secretary-General of the United Nations Ban Ki-moon. ${ }^{40}$ The Principles are intended to serve as a guide to all businesses in their interactions with children, and as such they are not binding. They identify a comprehensive range of actions that all businesses should take to both prevent and address adverse impacts connected with their activities and relationships, and to maximize positive business impacts on children's lives. ${ }^{41}$ This way the CRB Principles aspire to be a key reference point for existing and future voluntary and other initiatives on business and children, and as a basis for the promotion of multi-stakeholder collaboration. ${ }^{42}$

The CRB Principles' drafting process started in 2010 and together with the three leading organisations, other human and children's rights organisations have participated in the process. During 2011 these organisations convened meetings and engaged in online consultation with over 600 business leaders, civil society and government representatives as well as experts and children. ${ }^{43}$ Children participated through a Child Participation Strategy, intended to ensure that they were respected as equal stakeholders in the initiative and at the same time build their capacity to engage with business and understand businesses' responsibilities to respect and support their rights. During the summer of 2011, consultations with over 400 children, aged 7-17, were held in nine countries. ${ }^{44}$ The results of these consultations were published by UNICEF, the Global Compact and Save the Children in a report entitled 'How Business Affects Us'. ${ }^{45}$ This widely participatory process is fully in line with the CRC's provisions on children's participation and the right to have their voices heard during the development

\footnotetext{
${ }^{39}$ CRB Principles, (n 1).

40 Secretary-General Ban Ki-moon: Children's Rights and Business Principles, 11 March 2012: http://www.youtube.com/watch?v=CuOyJ--d3eg\&feature=youtu.be

${ }^{41}$ Global Compact, A Call to Business to Respect and Support Children's Rights, Press Release, 12 March 2012: http://unglobalcompact.org/news/197-03-12-2012 42 Ibid.

${ }^{43}$ Global Compact, Development of the Children's Rights and Business Principles: http://www.unglobalcompact.org/Issues/human_rights/childrens_principles/developm ent.html
}

${ }^{44}$ The countries were: Brazil, Argentina, Philippines, Zambia, Bangladesh, Ethiopia, Senegal, Paraguay and Peru, The children were asked to share their perspective about how business affects their lives, families and communities and review a set of draft Principles. Global Compact, ibid.

45 UNICEF, Global Compact and Save the Children, How Business Affect Us. Children and young people share their perspectives on how business impacts their lives and communities, June-August 2011:

http://resourcecentre.savethechildren.se/library/how-business-affects-us-childrenand-young-people-share-their-perspectives-how-business 
of policies affecting them. It further provides important legitimacy to the CRB Principles.

The Principles are drafted using rights-based language, recognising children as the bearers of rights rather than the recipients of corporate kindness. This represents an advance with regards to previous experiences of corporate social responsibility instruments. In this regard, the CRB Principles make reference to how they are derived from recognised human rights standards including the CRC and its Optional Protocols and the relevant ILO Conventions. However, and in line with Ruggie's Guiding Principles on business and human rights, they are clear in asserting that "they do not create new international obligations." ${ }^{46}$ In this regard they are firmly rooted in Ruggie's tripartite framework and rely on the general business responsibility to respect human rights as defined by the framework and the Guiding Principles. The CRB Principles reinforce the distinction between obligations and responsibilities for states and businesses respectively and do not move beyond Ruggie's premise that businesses are solely legally bound by national law. ${ }^{47}$ They even go further in the distinction of the roles and scope of responsibilities by adding yet another level of engagement: commitment, as distinct from responsibility. In this regard they assert that businesses have a corporate responsibility to respect and corporate commitment to support children's rights. The CRB Principles are thus based on recognition of corporate responsibility as the minimum that is required of business and defined as:

"avoiding any infringement of the human rights of others, including children, and addressing adverse human impact with which the business is involved. The corporate responsibility to respect applies to business's own activities and its business relationships, linked to its operations, products and services."

Whilst the corporate commitment to support is strongly encouraged, even if not required, and it is defined as:

"voluntary actions that seek to advance human rights, including children's rights, through core business activities, strategic social

\footnotetext{
${ }^{46}$ CRB Principles, Preamble, at 12.

47 The Preamble explicitly states: 'Governments at all level have the duty to respect and fulfill children's rights. However, all societal actors, including business, must comply with applicable national law and respect international standards on children's rights'. CRB Principles, at 13.
} 


\section{BUSINESS, HUMAN RIGHTS AND CHILDREN: THE DEVELOPING INTERNATIONAL AGENDA}

investment and philanthropy, advocacy and public policy engagement, and working in partnership and other collective action."

Each Principle is drafted according to this distinction, specifying what is considered as part of the responsibility to respect and suggestions as to how businesses can extend their support for children's rights if they voluntarily choose to do so.

Conforming to Ruggie's model the CRB Principles are addressed to all businesses, regardless of their size, sector, location, ownership and structure. They also apply to business relationships, that is, "those relationships a business has with business partners, entities in its value chain, and any other State or non-state (government or non-governmental) entity directly linked to its business operations, products or services". ${ }^{49}$ This definition mirrors that of the UN Guiding Principles, ${ }^{50}$ but it then goes further to "include indirect relationships in an enterprise's value chain, beyond the first tier, as well as a majority and minority shareholding positions in joint ventures". 51

The CRB Principles cover a wide range of key issues - from child labour to marketing and advertising practices to the role of business in aiding children affected by emergencies, the impact of land acquisition and security arrangements. The CRB Principles are generally gender-sensitive, recognising that girls and boys may face different risks in relation to business activities.

CRB Principle 1 lays down the general responsibility for business with regards to children's rights. It reads: "All business should meet their responsibility to respect children's rights and commit to supporting the human rights of children". This responsibility mirrors the general one established in the UN Guiding Principles, therefore demanding a public policy commitment to human rights, the development of due diligence processes to identify and address human rights impacts and the participation in remediation processes when their activities give rise to adverse consequences on human rights. The value of the CRB Principles is its concentration on children's rights, something which was absent in the UN Guiding Principles. Of particular importance is the definition of human rights due diligence as needing to be child sensitive. CRB Principle 1 specifically requires businesses to identify and assess actual or potential adverse impact on children's rights through processes which involve meaningful consultation with children; it demands the use of appropriate qualitative and quantitative indicators and the resource to feedback from internal and external sources, including affected children and their families; and requires businesses to communicate externally their

\footnotetext{
${ }^{48}$ CRB Principles, Introduction, at 5.

${ }^{49}$ CRB Principles, Glossary, at 6.

${ }^{50}$ UN Guiding Principles, (n 10), Commentary to Principle 13.

${ }^{51}$ CRB Principles, Glossary, at 6.
} 
efforts to address their impact on children in a way that it is accessible to the intended audience. CRB Principle 1 also advances the definition of remediation processes specifically intended to address children's rights impact by establishing that these processes should be child-sensitive, accessible to girls and boys, their families and those who represent their interests.

CRB Principles 2-4 mainly deal with labour related rights. They establish that all business should: 2) Contribute to the elimination of child labour, including in all business activities and business relationships; 3) Provide decent work for young workers, parents and caregivers; 4) Ensure the protection and safety of children in all business activities and facilities. CRB Principle 4 explicitly suggests that business should develop a child protection code of conduct for business operations, as part of the corporate commitment component of the Principle. It is rather surprising that this reference to a child specific code only appears in this one place.

CRB Principles 5 and 6 deal with children as consumers of products and services and establish that all business should: 5) Ensure that products and services are safe and seek to support children's rights through them; 6) Use marketing and advertising that respect and support children's rights.

The following CRB Principles are particularly innovative and respond to the comprehensive approach to the risks faced by children and their needs. CRB Principle 7 states that all businesses should respect and support children's rights in relation to the environment and to land acquisition and use. This is particularly important because until now children have been largely neglected when considering the impact large investment projects requiring land acquisition have had on them, as well as how their health, livelihood and future development may be affected by the environmental consequences of commercial operations. ${ }^{52}$ CRB Principle 7 includes, with regards to the corporate responsibility to respect:

“a) respecting children's rights in relationship to the environment, when planning and implementing environmental and resource use strategies, ensuring that business operations do not affect children's right through damaging the environment or reducing access to natural resources and ensuring that the rights of children, their families and communities are addressed in contingency plans and remediation for environmental and health damage derived from their operations and;

\footnotetext{
52 According to the World Health Organisation each year around three million children under the age of five die due to environment-related diseases, see WHO, Global Plan of Action for Children's Health and the Environment (2010-2015), http://www.who.int/ceh/cehplanaction10_15.pdf (undated).
} 


\section{BUSINESS, HUMAN RIGHTS AND CHILDREN: THE DEVELOPING INTERNATIONAL AGENDA}

b) respecting children's rights as an integral part of human rights considerations when acquiring or using land, which includes avoiding or minimising displacement of communities, engaging in meaningful consultation, including seeking prior and informed consent of indigenous peoples and in particular respecting children's rights, specially their right to education, protection, health, adequate food and adequate standard of living and participation when resettlement is carried out, as well as when providing for compensation."

Notably, there is no reference made to child-sensitive consultation processes in this particular provision.

CRB Principle 8 refers to the responsibility to respect and support children's rights in security arrangements, which is a particularly important issue, especially when businesses operate in highly volatile contexts or conflict situations, which per se pose increased risks to children. CRB Principle 9 calls on all businesses to help protect children affected by emergencies, suggesting that as part of their commitment to support children's rights they make a positive contribution to sustainable peace and development. Finally CRB Principle 10 states that all businesses should reinforce community and government efforts to protect and fulfil children's rights. The main responsibility in this regard is not to undermine government efforts to protect and fulfil children's rights, recognising that respect for the rule of law and use of responsible business practices, including the payment of taxes, are essential for governments to meet their obligation to protect and fulfil children's rights.

As a voluntary instrument the CRB Principles only constitute international aspirations for the business community to assume human rights responsibilities. The Principles therefore suffer from the same problem as other voluntary initiatives with regards to how to guarantee compliance, lack of sanctions for non-compliance and lack of mechanisms for reparation and redress. However, they are a very important step because they provide a comprehensive framework of issues that businesses should look out for and raise consciousness and direct future practice, which may have an important practical impact if it translates into the transformation of business practices.

\section{UNITED NATIONS COMMITTEE ON THE RIGHTS OF THE CHILD, GENERAL COMMENT 16}

In 2013 the UN Committee on the Rights of the Child adopted and published General Comment 16 on state obligations regarding the impact of 
the business sector on children's rights. ${ }^{53}$ The General Comment has emerged from the context of the Committee's previous discussions relating to children and the private sector and the simultaneous development of a more robust framework dealing with business and human rights generally, as mentioned above. General Comments of course are not legally binding and have received a mixed reception from states. However General Comments are recognised as indicators as to how the relevant treaty body believes certain provisions of the Convention it oversees should be interpreted. ${ }^{54}$ In particular, the Committee on the Rights of the Child also relies on its General Comments when evaluating the compliance of state parties to their obligations under the Convention and it tends to refer systematically to them when delivering Concluding Observations on state parties' progress. ${ }^{55}$ Many General Comments elaborate on the interpretation of a specific article contained in a Convention; however General Comment 16 is more unusual in that it seeks to explore business activities vis-à-vis the Convention as a whole and to clarify the scope of state obligations with regards to this sector. This is an ambitious task given the holistic approach of the CRC, which contains a wide range of rights and covers various specific circumstances, e.g. migrant children, disabled children and those otherwise marginalised. The Committee on the Rights of the Child is also the first UN Treaty Body to examine the relationship between business and human rights in a dedicated Comment.

General Comment 16 provides states with a framework for implementing the CRC as a whole in relation to the business sector, while focussing on specific contexts where the impact of business activities on children's rights can be most significant. In doing so it acknowledges the importance of several instruments directly related to business and human rights, including Ruggie's framework, and specifically mentions the CRB Principles, analysed above. ${ }^{56}$ The Committee adopts the same approach as Ruggie in maintaining that it is primarily the state's obligation to protect children's rights and that states have a duty to ensure that business activities comply with the required human rights standards. In this regard, it clarifies that a state will be in breach of its obligations under the CRC and its Optional Protocols when it fails to respect, protect and fulfil children's rights in relation to business activities and operations that impact on them. ${ }^{57}$ States' obligations to respect, protect and fulfil children's rights in the context of business activities include providing

\footnotetext{
${ }^{53}$ UN Committee on the Rights of the Child, (n 2).

54 See generally, P Alston and J Crawford (eds) The Future of UN Human Rights Treaty Monitoring (Cambridge University Press, 2000).

55 J E Doek, (n 27) 105.

${ }^{56}$ UN Committee on the Rights of the Child, (n 2) para 7.

${ }^{57}$ Ibid, para 25.
} 


\section{BUSINESS, HUMAN RIGHTS AND CHILDREN: THE DEVELOPING INTERNATIONAL AGENDA}

effective remedies and reparations in case of violations by business. ${ }^{58}$ Children's rights are mainstreamed in the business sector as per General Comment 16 as it clearly declares that "all business-related policy, legislation or administrative acts and decision-making should be transparent, informed and include full and continuous consideration of the impact on the rights of the child." ${ }^{59}$ The General Comment calls on states to facilitate the development of an environment in which children's rights are respected. The Committee considers that the obligations assumed by states under the CRC are obligations of result and of conduct. Therefore, as it has maintained previously states are not relieved of their obligations under the CRC and its Protocols if their functions are delegated or outsourced to a private business (or to a non-profit organisation for that matter).

However, the Comment also foresees a direct role for business:

"duties and responsibilities to respect the rights of children extend in practice beyond the state and state-controlled services and institutions and apply to private sector actors and business enterprises. Therefore all business must meet their responsibilities regarding children's rights and States must ensure that they do so." 60

The Comment then adds that part of this responsibility of business is not to undermine the state's ability to meet its obligations towards children.

The due diligence standard is identified as a means for measuring compliance. What that means of course, is that a state will be held responsible if it fails to take the appropriate steps to prevent, investigate, adjudicate and redress any alleged violations of children's rights. ${ }^{61}$ However, the Committee also relies on due diligence as the standard to facilitate businesses' own responsibilities towards children's rights. In particular due diligence allows businesses to identify, prevent and mitigate their impact on children's rights including across their business relationships and within global operations. ${ }^{62}$ This represents a clear nexus with the UN Guiding Principles. However, in contrast to the CRB Principles, the Committee does not define what should be understood as child rights due diligence and whether it differs from general human rights due diligence processes. In this regard, the lack of references to specific child inclusive processes and explicit requirements for child participation in consultation and remediation processes is a missed opportunity. It is, again, the state's responsibility to facilitate the processes of

\footnotetext{
${ }^{58}$ Ibid, paras 30-31.

${ }^{59}$ Ibid, para 26.

${ }^{60} \mathrm{Ibid}$, para 8 .

${ }^{61}$ Ibid, para 28.

62 Ibid. para 62.
} 
corporate child rights due diligence, and to provide the adequate environment for it. In fact, the onus is on states to lead by example with regard to state owned enterprises and to publicly communicate their impact on children's rights. Where there is a high risk of business enterprises being involved in violations of children's rights because of the nature of their operations or their operating contexts, states should require a stricter process of due diligence and an effective monitoring system.

General Comment 16 does not consider right by right what the impact of business activities may be on children's rights and how far the obligations of states and responsibilities of business reach. It rather focuses on the four cardinal principles of the Convention, namely, the right to non-discrimination (art 2), the best interests of the child (art 3(1)); life, survival and development (art 6); and the right to be heard (art 12) with which all business activities must conform to ensure a child's rights approach is applied holistically. It provides illustrative examples of how business activities may impact upon the lives of children with regards to each principle. Pursuant to the right to nondiscrimination, the Committee understands that Article 2 demands states ensure that all legislation, policies and programmes dealing with business issues are not discriminatory towards children either intentionally or unintentionally, both in content and implementation. The General Comment places an obligation on states to prevent discrimination in the private sphere, as well as to provide remedies for when discrimination has occurred. Part of states' obligations is to provide a supportive environment for businesses so they can respect the right to protection from discrimination. ${ }^{63}$

In respect of the best interests of the child, as per Article 3(1), the Comment states unequivocally that states are obliged to integrate and to apply this principle in all legislative, administrative and judicial proceedings concerning business activities and operations that directly or indirectly impact on children. ${ }^{64}$ The best interests of the child now requires to be read in conjunction with General Comment 14, which was published by the Committee in May 2013. ${ }^{65}$ The obligation on the state is not merely to ensure the best interests of the child have been taken into consideration, but it must also be able to explain how the principle has been weighed in relation to other considerations. ${ }^{66}$ This becomes all the more important when states are called upon to weigh competing priorities, such as short term economic concerns over longer term development issues. Specific norms and policies which

\footnotetext{
${ }^{63}$ Ibid, paras 13-14.

${ }^{64}$ Ibid, para 15.

${ }^{65}$ UN Committee on the Rights of the Child, General Comment 14 on The Right of the Child to Have His or Her Best Interests Taken as a Primary Consideration (art 3, para 1), CRC/C/GC/14, 29 May 2013.

${ }^{66}$ Ibid, para. 12.
} 


\section{BUSINESS, HUMAN RIGHTS AND CHILDREN: THE DEVELOPING INTERNATIONAL AGENDA}

states should consider in this regard are those related to employment, taxation, corruption, privatisation, transport and other general economic, trade or financial issues. ${ }^{67}$

General Comment 16 (para 18) recalls Article 6 and General Comment $5{ }^{68}$ relating to the child's right to life, survival and development. This is a "holistic concept, embracing the child's physical, mental, spiritual, moral, psychological and social development." ${ }^{\circ 9}$ The way in which business enterprises can impact on the realisation of Article 6 is illustrated by reference to, for example, environmental degradation and contamination and how these may occur as a result of business activity and in turn may compromise children's rights to health, food security and access to safe drinking water and sanitation. A wide range of business activities and policies can have an impact on children's rights to life, survival and development, as is illustrated by the examples given in the Commentary. Among them, and in clear connection with the CRB Principles, are those related to decent work for parents and carers (Principle 3), the marketing of products which may be harmful for children (Principle 6) and the access to land and natural resources (Principle 7).

The right of the child to be heard (Article 12) again has to be looked at in the context of General Comment $12^{70}$ and the relevant articles contained within the Convention on the Rights of Persons with Disabilities. As anticipated Article 12 is considered core and General Comment 16 emphasises the need for businesses to consult with children in situations where the enterprises' activities may impact upon children's rights, or indeed have had an impact. The obligation to ensure that children are listened to falls on states, whose responsibility it is to provide the necessary environment and frameworks to ensure children are consulted. Voluntary participation of children in judicial procedures, conciliation and arbitration mechanisms is now required by General Comment 12 .

The Committee also provides a non-exhaustive set of specific circumstances in which "the impact of business enterprises can be significant and where States' legal and institutional frameworks are often insufficient, ineffective or under pressure", ${ }^{71}$ and in which therefore business activities and operations are most likely to impact on children's rights. This way the

\footnotetext{
${ }^{67}$ UN Committee on the Rights of the Child, (n 2) para 15.

${ }^{68}$ UN Committee on the Rights of the Child, (n 33).

${ }^{69}$ See Official Records of the General Assembly, Fifty-ninth Session, Supplement No. 41 (A/59/41), annex XI, para 12.

${ }^{70}$ UN Committee on the Rights of the Child, General Comment 12 The right of the child to be heard, $\mathrm{CRC} / \mathrm{C} / \mathrm{GC} / 12$,

20 July 2009.

${ }^{71}$ UN Committee on the Rights of the Child, (n 2) para32.
} 
Comment elaborates further on the private provision of services for the enjoyment of children's rights; the impact on children of the informal economy; children's rights and global business operations; the role of states as part of international organisations; and finally the relationship between business and children in the context of emergencies and conflict situations. This final point was also addressed by the CRB Principles.

The Committee recognises that one of the most critical factors influencing the impact of business activities on children's rights is the lack of implementation or poor enforcement of laws regulating businesses. ${ }^{72}$ Section VI is therefore devoted to establishing a framework for implementation which foresees the development by states of measures of various kinds: legislative, regulatory and enforcement, remedial, policy, coordination and monitoring, collaborative and awareness-raising. Some have been mentioned already, such as the assistance to businesses to develop their own due diligence processes to assess, prevent, mitigate and remediate harm to children's rights. Another one is to strengthen regulatory agencies which have responsibility for the overseeing of standards, such as health and safety, education, labour and advertising and marketing. These have to be strengthened so they have sufficient power and resources to monitor and investigate complaints, and to provide and enforce remedies for the abuse of children's rights. Interesting measures suggested in the implementation section include the definition of child rights impact assessments ${ }^{73}$ and the specific role for national human rights institutions in raising awareness of the CRC's provisions amongst business enterprises. ${ }^{74}$ States also have to disseminate laws relating to children's rights and business, including disseminating to business enterprises. The training of judges and other administrative officials including lawyers and legal aid providers is also recommended. This is to ensure the correct application of the CRC and its Protocols on business and children's rights. States have to provide for an effective remedy through judicial or non-judicial mechanisms and ensure effective access to justice.

Children frequently do not have full legal standing in some judicial systems or their access is highly restricted for legal or practical reasons. The Committee envisages as part of states' obligations that they should focus their attention on removing social, economic and juridical barriers so that children can in practice have access to effective judicial mechanisms without discrimination of any kind. ${ }^{75}$ Throughout the General Comment there is an emphasis on facilitating children's access to effective remedies, especially those children who may face additional barriers in respect to, for example,

\footnotetext{
72 Ibid, para 61.

${ }^{73}$ Ibid, paras 78-81.

${ }^{74}$ Ibid, para 83.

${ }^{75}$ Ibid, para 68.
} 


\section{BUSINESS, HUMAN RIGHTS AND CHILDREN: THE DEVELOPING INTERNATIONAL AGENDA}

language or disability. It is not just a child friendly, but a child respecting approach, for which the General Comment calls, and the need to create the appropriate environment for that to flourish. There is, with respect to the CRC, the potential of the Optional Protocol on a communication procedure. This would allow for individuals or their representatives to initiate a complaints procedure against an agreeing state party. However at the time of writing this has not been ratified by the necessary state parties ${ }^{76}$ and the option for this mechanism to be an effective instrument to deal with business related children's rights abuse is still very far away.

\section{CONCLUSION}

The instruments analysed in this article are part of an important trend: the development of a comprehensive response to the risks children's rights face from business activities. Until recently international focus has been somewhat ad hoc and sector-specific. This has been evidenced by the concentration on the regulation of child labour and economic exploitation of children and the consequences of the privatisation of public services on their rights. The international legal instruments regulating these spheres placed the responsibility in the fulfilment of the rights of the child exclusively on states. However, both the CRB Principles and General Comment 16 acknowledge a responsibility of business vis-à-vis children's rights beyond that of the state. Even in the case of the General Comment, which is fundamentally addressed to states, it contains clear direct references to what is expected of business within this ambit. Whilst only states have direct obligations with regards to children's rights, increased recognition of business responsibilities in instruments such as the ones analysed here, contribute to, and may continue to contribute to, the creation of fertile ground for increased demands on business. This may lead to indirect obligations in international law and the development of direct obligations in national systems.

The CRB Principles and General Comment 16 are also important because they are based on the conception of children as rights bearers. This goes beyond the traditional perception, in the context of business activities, that children are mainly objects of protection from economic exploitation and abuse as members of the labour force or recipients of welfare services. Children have rights also in relation to business, and they should be included in every step of the way to guarantee that economic activities do not harm them. Importantly both instruments widen the protection of children to include areas which had previously not received attention, such as the needs of children as consumers of products, services and marketing strategies; their

${ }^{76}$ Currently only six of the ten required state parties have ratified the Optional Protocol. 
rights in the context of large economic projects which affect their environment and their communities; and the specific challenges and risks to which they are exposed to in situations of armed conflict and emergencies.

Therefore, although the documents discussed above are not legally binding they do represent the development of a more comprehensive strategy rather than the piecemeal approach which has, until recently, been characteristic of the field of children's rights and business. There is a substantive body of international instruments on the issue of children's rights as well as an increased number of international initiatives regarding business and human rights. Cross-reference has to be made and cognisance given to the ramifications each has for the others. Equally, businesses themselves are contributing by acknowledging their own role in the fulfilment of children's rights. However a plethora of instruments and public declarations of good will in itself will not promote and protect the rights of children: it is important that these are realised in practice and that the appropriate checks and balances, informed by robust monitoring, be implemented.

The current progress is encouraging but for effective promotion and protection of children's rights, states have to take the necessary steps in their domestic legal systems and businesses have to discharge their responsibilities diligently, taking into account all those likely to be affected by their activities. However whether this can be realised while the framework around children's rights and business is of a voluntary nature remains to be seen. 